Akademia im. Jakuba z Paradyża w Gorzowie Wielkopolskim

ORCID: 0000-0001-8293-0188

\title{
Ewa Horyń, Stownictwo z zakresu górnictwa solnego XVI-XVIII wieku na tle polszczyzny ogólnej. Wydawnictwo Naukowe Uniwersytetu Pedagogicz- nego, Kraków 2018, ss. 242
}

Cel swojej rozprawy sformułowała autorka następująco:

Głównym celem niniejszej monografii jest zebranie i analiza polskiej leksyki z zakresu górnictwa solnego w XVI-XVIII w. Prezentacja i opis materiału leksykalnego skoncentrowane są głównie na przedstawieniu słownictwa, które swoją tematyką obejmuje dwie najważniejsze sfery - eksploatację soli oraz handel nią. Dobór zebranego materiału nie jest przypadkowy. Został on zgrupowany wokół dwunastu kategorii znaczeniowych istotnych dla odtworzenia leksyki związanej z tą gałęzią przemysłu (s. 7).

Deklaracja metodologiczna, choć zwięzła:

Studia nad wskazanym korpusem leksykalnym wpisują się w nurt badań związanych z polem znaczeniowym. Metodą badawczą wykorzystaną w pracy w celu uporządkowania zebranego słownictwa jest teoria pól oraz składnikowa analiza znaczeń (s. 8),

jest moim zdaniem w zupełności wystarczająca - tym bardziej że po niej następuje przypomnienie recepcji teoria pola na gruncie polskim (Danuta Buttler, Walery Pisarek, Krystyna Pisarkowa, Ryszard Tokarski, Stanisław Karolak, Władysław Miodunka, Ewa Młynarczyk i inni, s. 8-10), zakończone drugą deklaracją, uściślającą tę pierwszą:

W niniejszej pracy przyjmuję onomazjologiczne kryterium porządkowania zebranego słownictwa. Przez pole znaczeniowe rozumiem uporządkowany wewnętrznie zbiór jednostek leksykalnych powiązanych wspólnym elementem znaczeniowym - archisemem, dalsze zaś ich różnicowanie następuje na podstawie semów dyferencjalnych. Podstawą gromadzenia materiału badawczego była więc obecność archisemu - 'to, co ma związek $\mathrm{z}$ wydobyciem soli'. Poszczególne jednostki leksykalne (wyrazy i połączenia wyrazowe) wchodzące w skład opisywanego słownictwa zostały pogrupowane w dwanaście pól wyrazowych według cech semantycznych zwanych semami dyferencjalnymi (s. 10). 
Te dwanaście pól to: nazwy soli, nazwy brył solnych, nazwy przedsiębiorstw solnych, nazwy miejsc, nazwy osób, nazwy robót górniczych, nazwy pojemników, nazwy narzędzi i urządzeń górniczych oraz elementów wyposażenia kopalni, nazwy miar, nazwy związane $\mathrm{z}$ organizacją pracy w kopalni, nazwy opłat i nazwy inne.

Po prezentacji wszystkich jednostek $\mathrm{z}$ danego pola następuje jego analiza w trzech częściach.

Jako pierwszą przedstawiam analizę leksykalno-semantyczną, w której staram się ustalić płaszczyznę hiperonimiczno-hiponimiczną badanych nazw, a także zobrazować relacje, jakie zachodzą pomiędzy poszczególnymi składnikami pól leksykalno-tematycznych. Analiza etymologiczno-strukturalna służy do przybliżenia mechanizmów powstawania poszczególnych nazw oraz pokazania ich budowy językowej. Analiza leksykograficzna ma zaś na celu opis badanego słownictwa pod kątem jego obecności w słownikach polszczyzny ogólnej. Opis ten zamyka tabela z notacjami słownikowymi. Symbol '+' oznacza występowanie hasła w danym słowniku, znak '-’ jego brak (s. 12-13).

Trzeba tu dodać, że autorka uwzględniła następujące słowniki ogólne języka polskiego: Słownik staropolski, Słownik polszczyzny XVI wieku, Słownik języka polskiego S.B. Lindego, tzw. Słownik warszawski i Słownik języka polskiego pod redakcją W. Doroszewskiego, co trzeba uznać za wybór trafny i wystarczający.

Dla historyka języka samoistną wartość informacyjną mają podstawowe wiadomości historyczne o górnictwie solnym, zawarte w rozdziale I (s. 15-18). Dla większości językoznawców, zwłaszcza najmłodszego pokolenia, przydatna i interesująca będzie także zawartość rozdziału II, relacjonującego stan badań nad polską leksyką specjalistyczną (zarówno terminologią, jak i leksyką profesjolektalną (s. 19-23), a następnie prezentującego charakterystykę leksyki górniczej (s. 23-25). Szczególny podziw dla ogromu pracy (kwerenda!) Ewy Horyń musi wzbudzić lektura rozdziału III, poświęconego opisowi źródeł. Są wśród nich zarówno teksty wydane drukiem, jak i nieopublikowane materiały rękopiśmienne, gromadzone przez $\mathrm{Mu}$ zeum Żup Krakowskich Wieliczka. Autorka za literaturą przedmiotu wyróżnia wśród nich źródła opisowe (opisy, inwentarze, rewizje, lustracje itd.) i normatywy (ordynacje, instrukcje, mandaty, zarządzenia itd.). Podziw budzi zwłaszcza liczba wyzyskanych źródeł rękopiśmiennych bądź opublikowanych w serii Studia i Materiały do Dziejów Żup Solnych w Polsce. Autorka skromnie (choć byłoby tu miejsce na ze wszech miar uzasadnioną dumę) konstatuje:

Materiały źródłowe, które zostały włączone do niniejszej monografii, są wystarczające do opisu pełnego obrazu profesjonalnej leksyki zawodowej z zakresu górnictwa solnego XVI-XVIII w. Ich łączna liczba obejmuje pięćdziesiąt dokumentów zróżnicowanych zarówno pod względem objętości, jak i treści. Co ważne, teksty te wzajemnie się uzupełniają. Część $\mathrm{z}$ nich bowiem przedstawia sprawy związane $\mathrm{z}$ funkcjonowaniem administracji żupnej kopalni, część zawiera kwestie dotyczące kontroli przedsiębiorstwa solnego, w innych zaś odnajdujemy treści ważne dla poznania dziejów techniki górniczej, wykonywanych prac górniczych, a także organizacji spławu w okresie istnienia żup krakowskich (s. 30). 
Można zatem stwierdzić, że rozprawa Ewy Horyń oparta jest na solidnych podstawach źródłowo-materiałowych.

Te podstawy, adekwatne do zgromadzonego materiału językowego instrumentarium badawcze (o którym była już mowa wyżej) oraz bardzo pożądane zalety warsztatu naukowego autorki (jak wysoki stopień akrybii filologicznej czy ostrożność w wyciąganiu wniosków i formułowaniu tez) stanowią o tym, że autorka osiągnęła zamierzony cel badawczy. Powstała praca obszerna (242 strony), wyczerpująca i bardzo wartościowa w planie merytorycznym.

Szczegółowe wyniki naukowe rozproszone są wśród opisu i analizy poszczególnych pól leksykalno-semantycznych (s. 31-196). Każdy historyk języka, a w szczególności badacz dziejów słownictwa specjalistycznego, znajdzie wśród nich takie, które go specjalnie zainteresują. Ogół historyków języka najbardziej chyba zainteresuje rozdział XVII Profesjolekt górnictwa solnego a polszczyzna ogólna. Wynika z niego, że - zresztą zgodnie z oczekiwaniami - najbogatszym źródłem badanego słownictwa, rejestrującym najwięcej (231) omówionych w pracy jednostek leksykalnych, jest Stownik warszawski. 182 jednostki leksykalne notuje Stownik języka polskiego S.B. Lindego, 148 - Stownik polszczyzny XVI wieku, 173 - Stownik języka polskiego pod red. W. Doroszewskiego, a tylko 129 - Stownik staropolski. Żaden z uwzględnionych przez autorkę słowników nie odnotował 229 wyrazów, które zachowały się (znane są dziś) jedynie w specjalnych źródłach dotyczących leksyki solnej. Jest to oczywiście najbardziej, najwęziej wyspecjalizowana część leksyki górnictwa solnego. Autorka konkluduje:

Opisana leksyka solna to leksyka ograniczona do komunikacji związanej z profesją, rzadko przedostająca się do polszczyzny ogólnej, bo wypełniająca siatkę pojęć, związaną z realiami górniczymi, nieznanymi szerzej (s. 206).

Powołując się na opinię Ewy Pajewskiej, słusznie dowodzi, że taka prawidłowość

potwierdza istnienie wielu terminologii, które są znane wyłącznie przedstawicielom danej dziedziny wiedzy lub praktyki i w ogóle nie wchodzą do obiegu ogólnego na skutek oddalenia od głównych nurtów gospodarki i życia społecznego (s. 207).

Najogólniejszy wynik (a zarazem postulat) naukowy, znowu z zasadnym powołaniem się na opinię Ewy Pajewskiej, sformułowała autorka następująco:

do badań dawnego słownictwa profesjonalnego zdecydowanie należy wykorzystać wiarygodne źródła, ponieważ one dość rzadko wchodzą lub w ogóle nie są włączane w skład korpusu źródeł wykorzystywanych przez słowniki ogólne. Obserwację tę potwierdza Pajewska, pisząc, że z braku «odpowiednich kryteriów uwzględniania terminologii w słownikach języka ogólnego, jej zasób w tych słownikach jest arbitralną decyzją autora, uzależnioną od jego pozajęzykowej znajomości danej dziedziny, co często skutkuje przypadkowym uwzględnieniem terminów z określonych dziedzin w słownikach języka ogólnego» (Pajewska 2003: 61), tym samym opis leksyki specjalnej, bazujący jedynie na źródłach leksykograficznych, staje się niekompletny (s. 207). 
Jeszcze raz trzeba podkreślić ogrom pracy autorki, wynikający z ekscerpcji źródeł nieznanych przeciętnemu historykowi języka polskiego. Trzeba też podkreślić fakt, że monografia Ewy Horyń wypełnia istotną lukę w dorobku badań nad polskim słownictwem specjalistycznym.

Książka (nie zauważyłem istotnych usterek, poza drobiazgami w rodzaju [na s. 220] uznania Doby średniopolskiej za pierwszą część fundamentalnej Historii języka polskiego Zenona Klemensiewicza) zainteresuje zapewne nie tylko językoznawców. Jestem też przekonany, że doczeka się gruntownej fachowej recenzji. 